UDC: 615.1:167/168:351.84

DOI: 10.15587/2519-4852.2019.190543

\title{
RESULTS OF STRUCTURAL ANALYSIS OF MEDICAL APPOINTMENTS OF QUERCETIN DRUGS AND ITS DERIVATIVES IN UKRAINE
}

\author{
S. Bobokalo, L. Almakaieva, H. Panfilova, O. Tsurikova
}

\begin{abstract}
Мета: провести аналіз структури лікарських призначень препаратів квериетину та його похідних в Україні.

Матеріали і методи. Використовувалися дані експертного опитування лікарів із 25 міст України, щзо проводилося упродовж 2017-2018 рр.. В опитування приймали участь лікарі різних спеціальностей, щзо мали «дуже високий» $(k \geq 0,91)$, «високий» $(k=0,71-0,90)$ та «задовільний» $(k=0,51-0,70)$ рівень компетентності. Зазначений показник визначався з використанням n'яти коефіцієнтів $\left(k_{1+n}\right)$, які характеризували рівень теоретико-прикладної підготовки фахівців з питань організації лікувальнодіагностичного прочесу хворих з різними видами ангіопатій. Використано історичний, аналітикопорівняльний, системний, логічний, гіпотетико-дедуктивний, математико-статистичний методи, а також метод експертного опитування.
\end{abstract}

Результати дослідження. Встановлено, щзо найбільша кількість призначень (51,82 \%) здійснювалась терапевтами/сімейними лікарями, а найменша - ендокринологами (3,6 \%). У переважсній більшості респонденти (окрім алергологів та ендокринологів) призначали зазначені препарати за основним діагнозом хворого. При иььому, лише терапевти/сімейні лікарі та кардіологи здійснювали призначення препаратів квериетину та його похідних за широким спектром розвитку клінічної картини перебігу патології, а саме за основним діагнозом, його ускладненнями та супутніми захворюваннями. Лікарі всіх спеціальностей, окрім отоларингологів відмітили факт використання у лікуванні супутніх патологій хворих препаратів квериетину та його похідних. Першу позицію (1-й рівень МКХ-10) займали лікарські призначення у разі лікування І-Хвороб системи кровообігу (78,97 \%), другу позицію - J-Хвороб системи дихання (11,30\%), а третю - К-Хвороб системи травлення (6,04\%). У структурі призначень для хворих на серцево-судинні патології найбільшу питому вагу мали призначення у разі лікування стенокардї (49,60\%), на другій позищї - хронічної ішемічної хвороби серия (21,61\%), а на третій - інших цереброваскулярних хвороб $(10,60 \%)$.

Висновки. Доведено, щуо найвищі показники призначень препаратів кверцетину та його похідних здійснювалися терапевтами/сімейними лікарями у лікування захворювань сериево-судинної системи за основним діагнозом, його ускладненнями та супутніми патологіями Низький рівень або відсутність призначень препаратів із означеної групи у лікарів інших спещіальностей потребує проведення подальших досліджень у зазначеному напрямку.

Ключові слова: ангіопатії; ангіопротектори; квериетин; лікарські призначення; частота лікарських призначень.

Copyright (C) 2019, S. Bobokalo, L. Almakaieva, H. Panfilova, O. Tsurikova. This is an open access article under the CC BY license (http://creativecommons.org/licenses/by/4.0).

\section{Introduction}

Violation of the integrity of the vessels and veins is one of the important chains in the pathogenesis of many pathological processes in the human body and development in the subsequent whole spectrum of sympathomplexes [1]. Therefore, the use of drugs that preserve the physiological parameters of the functioning of blood vessels and veins, contribute to the improvement of microcirculation, and as a consequence, reduce tissue swelling and improve the metabolic process can significantly prevent the development of life-threatening pathologies such as stroke, infarction chronic venous insufficiency, etc. [2]. The composition of this set of drugs include drugs, which are presented in different pharmacotherapeutic groups. All of them belong to the group of angioprotectors. According to the literature, angiotprotectors are becoming more and more widespread every year in the treatment of various types of angiopathies (diabetic, including retinopathies, nephropathies, pathological lesions of cerebral and coronary vessels, lower extremity vessels, etc.) rheumatoid diseases, atherosclerotic lesions of the vessels, diseases of the veins, as well as in trophic ulcers, etc. [2, 3]. The use of natural bioflavonoids derivatives in the treatment of a wide range of diseases does not lose its relevance $[1,4]$. The high biological activity of bioflavonoids, primarily quercetin derivatives, has been known for a long time, but they became more widely used in allopathic medicine only in the second half of the last century $[4,5]$. Since then, interest in quercetin and its derivatives has not only decreased, but due to the active development of pharmacology and related fields of knowledge has gained a new logical load. Currently, the literature presents data on antioxidant activity [6], vasodilating [7], antihypertensive [8] and antiatherogenic action $[6,9]$. In addition, quercetin preparations have shown significant data on cytoprotective properties in conditions of ischemia syndrome and reperfusion of various tissues and organs in humans [10]. The effective use of quercetin and its derivatives as antioxidant drugs makes it possible to state the presence 
of a whole complex of properties, first of all anti-anginal [8], liporegulatory [9], anticoagulant [1, 6], membranestabilizing $[10,11]$ and immunostimulating $[12,13]$. The presence of significant results in the ability to block the activity of free radicals, increase the efficiency of enzymatic antioxidant protection of cells, which generally creates positive prerequisites for maintaining the integrity of cell membranes necessitates the need for further studies in this direction $[6,10]$. According to experts, the most promising among the bioflavonoids on the membrane properties is a representative of inhibitors of lipoxygenases - corvitin (quercetin) [6,14]. Given the socioeconomic importance of increasing the incidence rates of the population, especially those of working age for malignant pathologies, studies on the evaluation of anticancer activity of the use of quercetin preparations are of considerable importance [15]. According to recent data, antitumor activity has been demonstrated in the treatment of various tumours, including in oncohematology [16, 17]. Given the above, it is logical that the market of quercetin and its derivatives is actively developing in Ukraine and abroad [18, 19]. According to the results of studies of domestic scientists, the vast majority of quercetin drugs belong to the group of over-the-counter drugs, which are released to pharmacy visitors within the framework of responsible self-medication on an outpatient basis [20]. In order to evaluate the prospect of introducing new generic drugs from the quercetin group and its derivatives into the organization of the treatment-and-prophylactic process, there is an objective need for research into the structure of medicinal prescriptions of drugs from the specified group. The purpose of our research was stated and determined.

The aim of the study - to analyse the structure of medicinal prescriptions of quercetin and its derivatives by doctors of different specialties.

\section{Planning (methodology) of research}

In order to achieve the aim of the research we have developed a scheme of research, which contained such stages as preliminary-preparatory, analytical-mathematical, resulting, system-generalizing, final. The main tasks in conducting the research in the specified stages, as well as their substantive load are presented in Table 1.

Table 1

Research methodology (main tasks and content of work stages)

\begin{tabular}{|c|c|c|}
\hline $\begin{array}{l}\text { The name of the } \\
\text { research stage }\end{array}$ & $\begin{array}{c}\text { The main task of } \\
\text { research }\end{array}$ & The content of the research \\
\hline $\begin{array}{l}\text { Preliminary- } \\
\text { preparatory }\end{array}$ & $\begin{array}{l}\text { Preliminary eval- } \\
\text { uation of objects } \\
\text { and research } \\
\text { methods. }\end{array}$ & $\begin{array}{l}\text { Carrying out preliminary analysis of the data of the specialized literature in the } \\
\text { chosen research area (domestic and foreign sources). Outline research objects. An } \\
\text { analysis of the tools used in similar research, the results of which are presented in } \\
\text { open databases. Conducting pilot studies with subsequent analysis of the results } \\
\text { obtained by specialists working in the same field of applied works. Assessment of } \\
\text { the level of competence of experts on the developed set of parameters, which } \\
\text { allow evaluating the level of theoretical and applied training of specialists in the } \\
\text { identified problems. Identify a group of experts with "very high" and "high" lev- } \\
\text { els of competence. Preliminary assessment of objective limitations in the conduct } \\
\text { of research and development of measures to minimize them. }\end{array}$ \\
\hline $\begin{array}{l}\text { Analytical- } \\
\text { mathematical }\end{array}$ & $\begin{array}{l}\text { Organize the } \\
\text { collection of rele- } \\
\text { vant statistical } \\
\text { material }\end{array}$ & $\begin{array}{l}\text { Collection of statistics. Preliminary analysis of the intermediate indicators of } \\
\text { the analysis and implementation of a set of optimization measures in making } \\
\text { the necessary calculations and generalizations. Determination of respondents' } \\
\text { levels of competence by a set of parameters and identification of respondents } \\
\text { with "very high", "high" and "satisfactory" levels of competence. Testing and } \\
\text { analysis of the effectiveness of using different statistical analysis packages to } \\
\text { obtain reliable and representative experimental data. }\end{array}$ \\
\hline Resulting & $\begin{array}{l}\text { Data processing } \\
\text { and evaluation of } \\
\text { the results obtained }\end{array}$ & $\begin{array}{l}\text { Conducting statistical processing of obtained data at the stage of their collec- } \\
\text { tion (analytical and mathematical stage of research). Assessment of the relia- } \\
\text { bility and representativeness of performance indicators in studies. }\end{array}$ \\
\hline $\begin{array}{l}\text { System- } \\
\text { generalizing }\end{array}$ & $\begin{array}{l}\text { Analysis of the } \\
\text { results of applied } \\
\text { research }\end{array}$ & $\begin{array}{l}\text { According to the results of the researches, their systematization is carried out } \\
\text { in order to assess the level of achievement of all tasks set at the beginning of } \\
\text { the work, which ultimately allow achieving the main aim of the research. } \\
\text { Comparison of self-reported data with research results conducted by other } \\
\text { scientists in a similar direction or using similar research objects and methods. } \\
\text { Generalization of the received data. Analysis of existing limitations in the } \\
\text { conduct, use and scientific interpretation of research findings. }\end{array}$ \\
\hline Final & $\begin{array}{l}\text { Assessment of the } \\
\text { scientifically ap- } \\
\text { plied value of the } \\
\text { obtained results and } \\
\text { outlining the pro- } \\
\text { spects of their } \\
\text { implementation in } \\
\text { the future }\end{array}$ & $\begin{array}{l}\text { Assessing the prospect of putting research results into practice with a view to } \\
\text { solving immediate socio-economic problems of the development of the } \\
\text { pharmaceutical supply system in Ukraine. Outline of perspective directions of } \\
\text { theoretical and applied researches on the specified subject. }\end{array}$ \\
\hline
\end{tabular}


The results of the research at the effective stage of the work were analysed (structural analysis) according to the following three groups of parameters: prescribing of quercetin and its derivatives according to the basic diagnosis, complication of the basic diagnosis and concomitant pathologies; the main diagnoses for which quercetin was prescribed according to the International Classification of Diseases 10 (ICD-10); a list of doctors by specialty who prescribe quercetin and the main diagnosis, complications of the basic diagnosis and related pathologies.

\section{Materials and methods}

Based on the purpose and methodology of applied research, we have outlined the following research objects and methods. The subjects of the research were selected data of anonymous questionnaire of doctors of different specialties with the use of a questionnaire, which included questions regarding the assessment of the frequency of prescriptions of quercetin preparations in the treatment of patients with various types of pathologies, including angiopathies, their complications and in the treatment of comorbidities. In addition, we used the operational data of the market research system "Pharmstandard" / "PharmXplorer", company "Proxima Research". The survey, which was conducted during 2017-2018, was attended by doctors (more than 400 respondents) of various specialties from 25 cities of Ukraine, working in the primary health care unit and in healthcare facilities, where they provide medical care to inpatients. Taking into account the fact that the survey used a single methodological approach, the comparison of the obtained data in the dynamics of the years seems justified. The sample of respondents was formed on a random basis, and the interim data were submitted for examination to independent experts who had "very high" and "high" levels of competence in the investigated issues. The level of this indicator in the group of respondents and experts was determined using five coefficients $(\mathrm{k} 1+\mathrm{n})$ of competence, which characterized the level of theoretical and applied training of specialists in the organization of medical and diagnostic process of patients with different types of angiopathies (practical experience, availability of qualifications, undergraduate training, a degree or title, participation in international professional conferences, etc.). All respondents and experts according to the $\mathrm{kn}$ index were divided by the level of competence at unequal intervals into 5 groups: "very low competence" $(\mathrm{k}=0.15-0.20)$; "low" $\quad(\mathrm{k}=0.21-0.50) ; \quad$ "satisfactory" $\quad(\mathrm{k}=0.51-0.70)$; "high" ( $\mathrm{k}=0.71-0.90)$; "very high" $(\mathrm{k} \geq 0.91)$. In the following, we used survey data of respondents with "satisfactory", "high" and "very high" levels of competence. As indicated earlier, a group of highly qualified experts with "very high" and "high" and level of competence was formed to conduct a preliminary assessment of the obtained results.

We used historical, analytical, comparative, systemic, logical, graphic, hypothetical-deductive, mathematical-statistical methods of scientific search and cognition. The main applied value in the conducted research was the method of expert interviewing. Frequency analysis of quercetin drugs and its derivatives was performed under three options, namely, "major diagnosis", "complication of basic diagnosis", and "comorbidities". All statistical data processing was performed using standard statistical analysis packages Statistica (version 12.0, StatSoft, Tulsa, USA) and Excel spreadsheet. A p value $<0.05$ was considered statistically significant.

\section{Results of the research}

According to the results of our research, we determined that in the structure of specialties, more than half of the prescriptions of quercetin and its derivatives were performed by therapists or family doctors on an outpatient basis. The second position were represented by cardiologists, and then by a significant margin - neurologists.

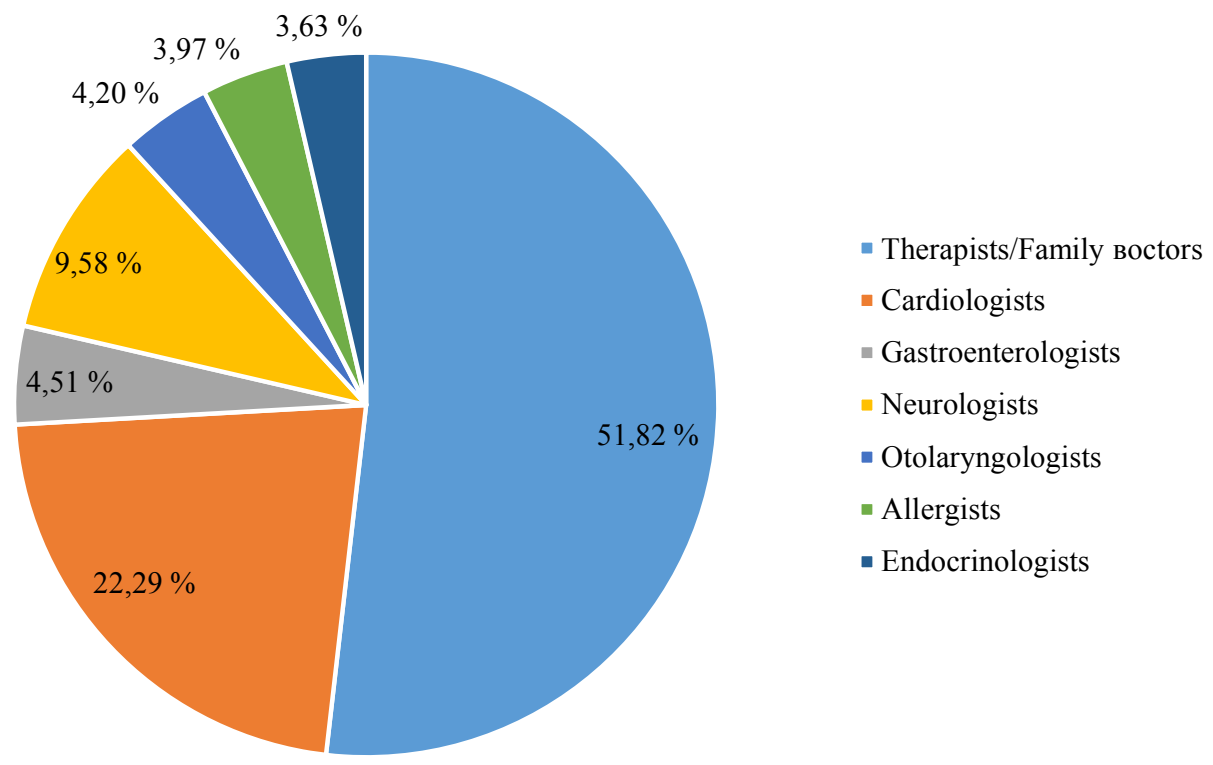

Fig. 1. Frequency analysis of quercetin drugs and their derivatives according to the main diagnosis, complication of the basic diagnosis and cumulative diagnosis in different specialties of doctors 
It should be noted that among the various doctors, the appointment of quercetin and its derivatives was performed by specialists from only 7 specialties. This includes therapists or family doctors, cardiologists, neurologists, gastroenterologists, otolaryngologists, allergists and endocrinologists. It should be noted that in the last 4 mentioned specialties of physicians there was a significant segmentation in terms of specific weight (\%) in the total number of appointments. Thus, this indicator ranged from a small range of values from $3.63 \%$ (endocrinolo- gists) to $4.51 \%$ (gastroenterologists). Doctors of other specialties who also participated in the survey (traumatologists, surgeons, ophthalmologists, etc.) did not note the fact that they would prescribe quercetin and its derivatives in the treatment of patients.

In accordance with the scheme of the research, we have outlined (Table 1); the next component of the systematic and general stage of work was the analysis of the structure of medicinal prescriptions of quercetin and their derivatives (Table 2).

Table 2

Results of structural analysis of medicinal products by primary diagnosis, its complications and concomitant pathologies by specialties of physicians

\begin{tabular}{|l|c|c|c|}
\hline \multirow{2}{*}{ Medical specialties } & \multicolumn{2}{|c|}{ Specific gravity of medicinal prescriptions (\%) in their total number (100.0 \%) } \\
\cline { 2 - 4 } & The main diagnosis & $\begin{array}{c}\text { Complications of the main } \\
\text { diagnosis }\end{array}$ & Associated pathologies \\
\hline Therapists / Family doctors & 89.7 & 7.1 & 3.2 \\
\hline Cardiologists & 95.4 & 3.4 & 1.2 \\
\hline Gastroenterologists & 95.2 & - & 4.8 \\
\hline Neurologists & 92.9 & - & 7.1 \\
\hline Otolaryngologists & 100.0 & - & - \\
\hline Allergists & - & - & 100.0 \\
\hline Endocrinologists & - & - & 100.0 \\
\hline
\end{tabular}

Noteworthy is the fact that the main diagnosis of prescribing quercetin and its derivatives in $100.0 \%$ of cases is carried out by doctors of such specialties as otolaryngologists, and in associated pathologies - allergists and endocrinologists. In our opinion, this fact is connected with the necessity of using these drugs precisely in the pathogenetic and symptomatic treatment of patients who consult the doctors of the specified specialties. In the insignificant range of values (from $89.7 \%$ to $95.4 \%$, the variance range was $1.19 \%$ ), the frequency of appointments of therapists / family physicians and cardiologists according to the preparations of quercetin and its derivatives in the pharmacotherapy of the main disease varied. At the same time, complication of the basic diagnosis causes prescription of preparations of quercetin and its derivatives only in a small number of doctors of the spec- ified specialties (therapists / family doctors - $7.1 \%$; cardiologists $-3.4 \%$ ). Thus, the presence of sympathocomplex, which is associated with the development of the pathological process (in most cases of chronic nature) by the doctors of these specialties, was not considered as important in justifying the prescriptions of quercetin and its derivatives. The above statement is also true in the case of the use of these drugs in the treatment of comorbidities in the practice of gastroenterologists $(4.8 \%)$, therapists / family doctors (3.2\%) and cardiologists (1.2\%).

Respondents were asked to note the diagnoses (ICD-10) and the pathologies for which they prescribe quercetin in the three options we selected (basic diagnosis, complications of basic diagnosis and related pathologies). The analysis of the structure of medicinal prescriptions are given in Table 3.

Table 3

Results of the structural analysis of medicinal products by diagnosis in accordance with ICD-10 (2019)

\begin{tabular}{|c|c|c|c|c|}
\hline \multirow{2}{*}{$\begin{array}{l}\text { Diagnosis } \\
\text { code* }\end{array}$} & \multirow[t]{2}{*}{ The diagnosis according to ICD-10 } & \multicolumn{3}{|c|}{ Specific gravity of medicines $(\%)$ by } \\
\hline & & MD** & CMD*** & $\mathrm{AP} * * * *$ \\
\hline J06.9 & Acute upper respiratory infection, unspecified & 100.0 & - & - \\
\hline I 10 & Essential (primary) hypertension & 100.0 & - & - \\
\hline I 20.0 & Unstable angina & 86.5 & 9.6 & 3.9 \\
\hline I 20.8 & Other forms of angina pectoris & 89.3 & 6.8 & 3.9 \\
\hline I 25.1 & Atherosclerotic heart disease & 77.1 & 8.7 & 14.2 \\
\hline I 25.2 & Old myocardial infarction & 89.5 & 4.7 & 5.8 \\
\hline I 25.9 & Chronic ischaemic heart disease, unspecified & 37.8 & 10.0 & 52.2 \\
\hline I 42.6 & Alcoholic cardiomyopathy & 100.0 & - & - \\
\hline I43.8 & Cardiomyopathy in other diseases classified elsewhere & 100.0 & - & - \\
\hline I 50.9 & Heart failure, unspecified & - & 86.5 & 13.5 \\
\hline I 67.3 & Progressive vascular leukoencephalopathy & 83.2 & - & 16.8 \\
\hline F 45.8 & Other somatoform disorders & 100.0 & - & - \\
\hline K 29.5 & Chronic gastritis, unspecified & 91.7 & 8.3 & - \\
\hline K 29.9 & Gastroduodenitis, unspecified & 94.5 & - & 5.5 \\
\hline K 30 & Dyspepsia & 100.0 & - & - \\
\hline R 04.0 & Epistaxis & 100.0 & - & - \\
\hline
\end{tabular}

Note: * diagnosis code for different levels of ICB-10 (edition 2019); **-the main diagnosis; ***-complication of the main diagnosis; ****_associated pathologies 
Systematizing the results of the conducted research can be argued as follows. In $100.0 \%$ of cases of treatment with primary diagnosis, doctors consider it advisable to administer the preparations of quercetin and its derivatives in the pharmacotherapy of the following pathologies: acute upper respiratory tract infections of multiple and unspecified localization; essential (primary) hypertension; alcoholic cardiomyopathy; cardiomyopathy in various diseases classified in other classes; other somatoform disorders; functional dyspepsia; bleeding from the respiratory tract. According to experts, these drugs are important in the treatment of the main disease in patients with cardiovascular pathologies $(37.8 \%$ in the case of ischemic cardiomyopathy; up to $89.5 \%$ in the pharmacotherapy of other forms of angina and previously myocardial infarction). High enough values of frequency of medical prescriptions these preparations are stored in gastroenterological practice. Thus, in the treatment of functional disorders, this indicator ranged from $91.7 \%$ (chronic gastritis unspecified) to $100.0 \%$ (functional dyspepsia). When carrying out pharmacotherapy of complications of the underlying disease, doctors prescribed quercetin and its derivatives much less frequently. Thus, the proportion (\%) of such appointments ranged from $4.7 \%$ (pre- viously myocardial infarction) to $10.0 \%$ ischemic cardiomyopathy. The profile of medications for the treatment of comorbidities with the use of quercetin and its derivatives was relatively more complex in nature. Thus, the highest values of the specific gravity (\%) of appointments were observed in the case of treatment of ischemic cardiomyopathy (52.2\%), and the lowest - unstable angina and other forms of angina $(3.9 \%)$. More than $10.0 \%$ of prescription drugs were observed in the case of pharmacotherapy of concomitant pathologies in patients with atherosclerotic heart disease (14.2\%), heart failure of unspecified etiology (13.5\%), and progressive vascular leukoencephalopathy $(16.5 \%)$.

These data suggest that quercetin and its derivatives are overwhelmingly dominant in the treatment of major pathologies, especially in cardiology and gastroenterology.

Taking into account the fact that during the questioning the doctors noted the diagnoses at different levels of ICD-10 at the next stage of work there was a need to systematize the results of the study. Thus, we further conducted a structural analysis of the specific gravity (\%) of medicinal prescriptions of quercetin and its derivatives according to the first level of ICD-10 (Fig. 2).

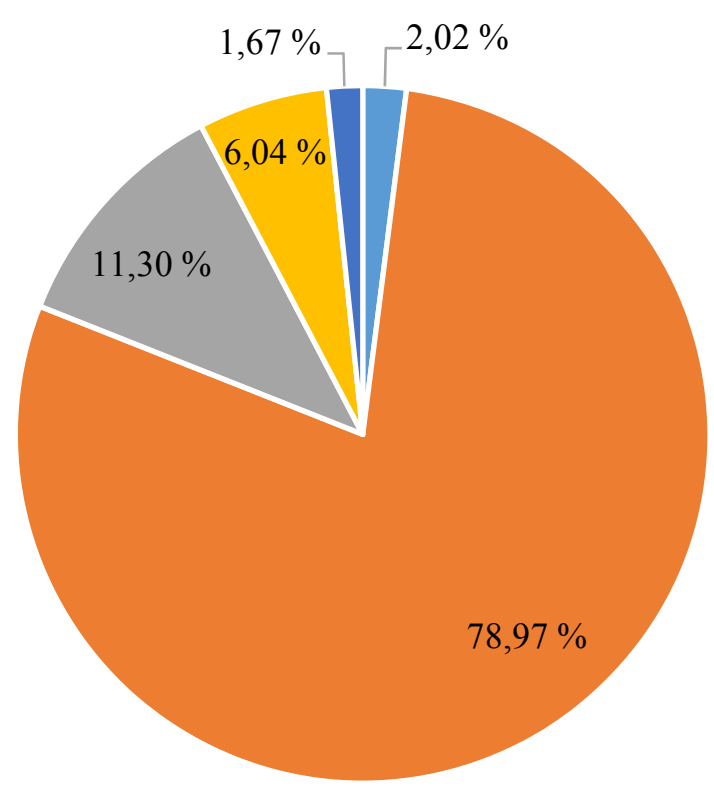

- F-Mental and behavioural disorders

- I-Diseases of the circulatory system

- J-Diseases of the respiratory system

- K-Diseases of the digestive system

- R-Symptoms, signs and abnormal clinical and laboratory findings, not elsewhere classified

Fig. 2. Analysis of the structure of medicinal prescriptions (specific weight, \%) in accordance with the first level of ICD-10

Commenting on the results it is impossible not to notice that more than $3 / 4$ of all appointments doctors carry out in the treatment of I-Diseases of the circulatory system $(78.97 \%)$, J-Diseases of the respiratory system $(11.30 \%)$ are presented in the second position with a significant gap, and in the third positions - K-Diseases of the digestive system $(6.04 \%)$. This is a rather indicative character of the profile of medicinal prescriptions for quercetin and its derivatives, performed by doctors of different specialties in Ukraine. Taking into account the unconditional dominance of medical prescriptions used in the treatment of cardiovascular pathologies, we conducted an analysis of their structure by the second level of classification ICD-10 (Fig. 3). 


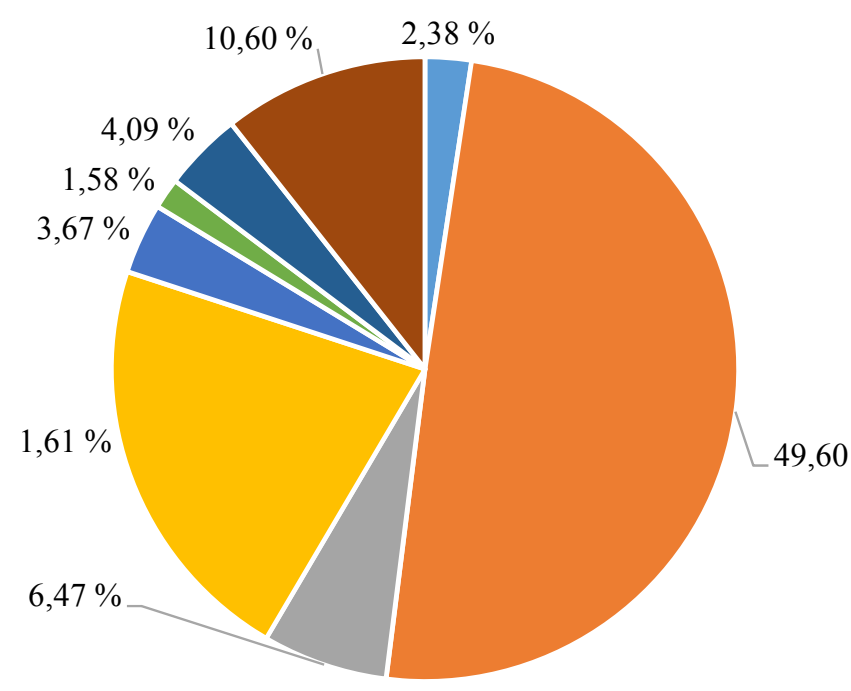

- I 10 Essential (primary) hypertension

- I 20 Angina pectoris

- I 21 Acute myocardial infarction

I 25 Chronic ischaemic heart disease

- I 42 Cardiomyopathy

- I 43 Cardiomyopathy in diseases classified elsewhere

- I 50 Heart failure

- I 67 Other cerebrovascular diseases

Fig. 3. The results of the structural analysis of medicinal products for patients with cardiovascular pathology at the 2nd level of ICD-10 (version 2019).

As we can see, about half of the medical prescriptions $(49.60 \%)$ are provided in the case of providing medical care to patients with angina pectoris. For every fifth patient diagnosed with chronic ischemic heart disease, doctors also prescribed quercetin and its derivatives, and one in ten was diagnosed with other cerebrovascular disease. The lowest specific gravity $(1.58 \%)$ had the prescription of the drugs being investigated in the treatment of cardiomyopathies in diseases presented in other groups of classification ICD-10 (I 67 according to ICD-10). In the treatment of all other cardiovascular pathologies, the proportion $(\%)$ of prescriptions for quercetin and its derivatives ranged from a small range of values, i.e. from $2.38 \%$ (cardiomyopathy) to $6.47 \%$ (acute myocardial infarction).

\section{Discussion of the research results}

After systematizing the results of the conducted research, it is necessary to identify three main characteristics, which we have established according to the structural analysis of medicinal prescriptions of quercetin and its derivatives. First, the fact that in the vast majority of respondents (except allergists and endocrinologists) these drugs are prescribed in case of treatment of a patient with a basic diagnosis is unconditional. Secondly, it draws attention to the considerable dominance of medicinal prescriptions in the treatment of cardiovascular patholo- gies, which is caused by the action of a whole set of factors, which are analysed in detail in the modern works of scientists [21, 22]. In this regard, the results of the studies do not contradict the data of the specialized literature [23], but only emphasize the medical and pharmaceutical importance of more active use of quercetin preparations and its derivatives in the treatment of pathologies of major socio-economic importance for the country. It is known that, among the causes of mortality of the population of Ukraine [24], as well as economically developed countries of the world, disturbances in the cardiovascular system, unfortunately, occupy the first position $[25,26]$. The results of our research, as well as the data of the specialized literature on the identified issues, make it possible to confirm the considerable potential in the use of quercetin preparations and its derivatives in the pathogenetic treatment of cardiovascular pathologies. Thirdly, it is necessary to note the fact of low level of medicinal prescriptions of drugs, which is studied in the practical activity of doctors of different specialties (except therapists / family doctors, cardiologists). Thus, given the wide range of pharmacotherapeutic activity of bioflavonoids in the treatment of various pathological conditions, including those that threaten the lives of patients [27], complications from their chronic course [28], we have questions about the low number or absence of prescriptions for quercetin and their derivatives in the work of doctors such specialties as ophthalmologists, oncologists, immunologists, neonatologists, surgeons, rheumatologists, etc. At the preliminary stage of our research, it might be necessary to analyse the protocols for providing patients with medical care in different specialties, approved by the relevant orders of the Ministry of Health of Ukraine, as well as international recommendations for the use of quercetin and its derivatives in the treatment of various pathological conditions. In addition, a separate direction for prospective research may be to analyse the level of information awareness of specialists in various medical specialties about the current state of applied research, demonstrating the activity of quercetin and its derivatives on a wide range of their pharmacotherapeutic action. This underlines the objective limitations of our research findings and will guide the direction of our prospective research on the topic.

Prospects for further research. Based on the above, we consider it necessary to point out that the main focus of our prospective studies will be to analyse the level of information awareness of doctors in various specialties on expanding the use of quercetin and its derivatives in the treatment of chronic pathologies, effective pharmacotherapy of which is important socioeconomic. The next area of research will be the organizational and economic substantiation of the possibilities of expanding the range of domestic preparations of quercetin and its derivatives, taking into account the modern profile of medicinal prescriptions of the specified drugs in the practical activity of doctors of different specialties.

\section{Conclusions}

According to the results of the systematization of the data of the profile of medicinal prescriptions of the preparations of quercetin and its derivatives, we can state the following. In the vast majority of these drugs are used 
by doctors in the pathogenetic and symptomatic treatment of patients with a primary diagnosis of patients with cardiovascular pathology, as well as in the treatment of chronic complications and comorbidities. In our opinion, one of the important factors that would significantly increase the level of consumption of these drugs, whose pharmacotherapeutic importance has not lost its rele- vance for national health systems over the years, is the expansion of state guarantees for the reimbursement of medicines to low-income populations, and patients with socially significant diseases.

\section{Conflict of interest}

There is no conflict of interest.

\section{References}

1. Del Bo', C., Bernardi, S., Marino, M., Porrini, M. et. al. (2019). Systematic Review on Polyphenol Intake and Health Outcomes: Is there Sufficient Evidence to Define a Health-Promoting Polyphenol-Rich Dietary Pattern. Nutrients, 11 (6), 1355. doi: http://doi.org/10.3390/nu11061355

2. Davis, J. M., Murphy, E. A., Carmichael, M. D. (2009). Effects of the Dietary Flavonoid Quercetin Upon Performance and Health. Current Sports Medicine Reports, 8 (4), 206-213. doi: http://doi.org/10.1249/jsr.0b013e3181ae8959

3. Aguirre, L., Arias, N., Macarulla, M. T., Gracia, A., Portillo, M. P. (2011). Beneficial effects of quercetin on obesity and diabetes. The Open Nutraceuticals Journal, 4 (1), 189-198. doi: http://doi.org/10.2174/1876396001104010189

4. Tutel'ian, V. A., Lashneva, N. V. (2013). Biologically active substances of plant origin. Flavonols and flavones: prevalence, dietary sourses and consumption. Vopr Pitan, 82 (1), 4-22.

5. Herrmann, K. (1976). Flavonols and flavones in food plants: a review. International Journal of Food Science \& Technology, 11 (5), 433-448. doi: http://doi.org/10.1111/j.1365-2621.1976.tb00743.x

6. Moon, Y. J., Wang, L., DiCenzo, R., Morris, M. E. (2008). Quercetin pharmacokinetics in humans. Biopharmaceutics \& Drug Disposition, 29 (4), 205-217. doi: http://doi.org/10.1002/bdd.605

7. Kleinedler, J. J., Foley, J. D., Alexander, J. S., Roerig, S. C., Hebert, V. Y., Dugas, T. R. (2011). Synergistic effect of resveratrol and quercetin released from drug-eluting polymer coatings for endovascular devices. Journal of Biomedical Materials Research Part B: Applied Biomaterials, 99B (2), 266-275. doi: http://doi.org/10.1002/jbm.b.31894

8. Tapsell, L. C., Neale, E. P., Probst, Y. (2019). Dietary Patterns and Cardiovascular Disease: Insights and Challenges for Considering Food Groups and Nutrient Sources. Current Atherosclerosis Reports, 21 (3). doi: http://doi.org/10.1007/s11883-019-0770-1

9. Galkina, E., Ley, K. (2007). Vascular Adhesion Molecules in Atherosclerosis. Arteriosclerosis, Thrombosis, and Vascular Biology, 27 (11), 2292-2301. doi: http://doi.org/10.1161/atvbaha.107.149179

10. Maksiutina, N. P., Moibenko, A. A., Mokhart, N. A. et. al. (2012). Bioflavonoidy kak organoprotektory (kvercitin, korvitin, kvertin). Kyiv: Naukova dumka, 274.

11. McKay, T. B., Karamichos, D. (2017). Quercetin and the ocular surface: What we know and where we are going. Experimental Biology and Medicine, 242 (6), 565-572. doi: http://doi.org/10.1177/1535370216685187

12. Chirumbolo, S. (2010). The Role of Quercetin, Flavonols and Flavones in Modulating Inflammatory Cell Function. Inflammation \& Allergy - Drug Targets, 9 (4), 263-285. doi: http://doi.org/10.2174/187152810793358741

13. Li, Y., Yao, J., Han, C., Yang, J., Chaudhry, M., Wang, S. et. al. (2016). Quercetin, Inflammation and Immunity. Nutrients, 8 (3), 167. doi: http://doi.org/10.3390/nu8030167

14. Probst, Y., Guan, V., Kent, K. (2018). A systematic review of food composition tools used for determining dietary polyphenol intake in estimated intake studies. Food Chemistry, 238, 146-152. doi: http://doi.org/10.1016/j.foodchem.2016.11.010

15. Men, K., Duan, X., Wei, X., Gou, M., Huang, M., Chen, L. et. al. (2014). Nanoparticle-Delivered Quercetin for Cancer Therapy. Anti-Cancer Agents in Medicinal Chemistry, 14 (6), 826-832. doi: http://doi.org/10.2174/1871520614666140521122932

16. Andriichuk, Ya. R., Davtian, L. L. (2015). (2015). Investigation of antineoplastic activity of chewing tablets based on dry oat extract and quercetin. ScienceRise, 7 (1 (12)), 71-73. doi: http://doi.org/10.15587/2313-8416.2015.47015

17. Huang, R.-Y., Yu, Y.-L., Cheng, W.-C., OuYang, C.-N., Fu, E., Chu, C.-L. (2010). Immunosuppressive Effect of Quercetin on Dendritic Cell Activation and Function. The Journal of Immunology, 184 (12), 6815-6821. doi: http://doi.org/10.4049/ jimmunol.0903991

18. Shi, Y., Su, X., Cui, H., Yu, L., Du, H., Han, Y. (2019). Combination of quercetin and Adriamycin effectively suppresses the growth of refractory acute leukemia. Oncology Letters, 18 (1), 153-160. doi: http://doi.org/10.3892/ol.2019.10299

19. Lukiienko, O. V., Kvitchata, H. I., Oklei, D. V., Plys, S. V. (2014). Doslidzhennia vitchyznianoho rynku likarskykh zasobiv dlia mistsevoho zastosuvannia pry khronichnii venoznii nedostatnosti. Aktualni pytannia farmatsevtychnoi i medychnoi nauky ta praktyky, 3 (16), 102-105.

20. Davtian, L. L., Andriichuk, Ya. R. (2014). Problemni aspekty formuvannia asortymentu likarskykh zasobiv z adaptohennoiu ta zahalnotonizuiuchoiu aktyvnistiu v Ukraini. Farmatsevtychnyi zhurnal, 4, 73-76.

21. Hodge, A., Bassett, J. (2016). What can we learn from dietary pattern analysis? Public Health Nutrition, 19 (2), $191-194$. doi: http://doi.org/10.1017/s1368980015003730

22. Cespedes, E. M., Hu, F. B. (2015). Dietary patterns: from nutritional epidemiologic analysis to national guidelines. The American Journal of Clinical Nutrition, 101 (5), 899-900. doi: http://doi.org/10.3945/ajen.115.110213

23. Rodríguez-Monforte, M., Flores-Mateo, G., Sánchez, E. (2015). Dietary patterns and CVD: a systematic review and meta-analysis of observational studies. British Journal of Nutrition, 114 (9), 1341-1359. doi: http://doi.org/10.1017/ s0007114515003177

24. Terenda, N. O. (2015). Smertnist vid sertsevo-sudynnykh zakhvoriuvan yak derzhavna problema. Visnyk naukovykh doslidzhen, 4, 11-13.

25. GBD 2016 Disease and Injury Incidence and Prevalence Collaborators. Global, regional, and national incidence, prevalence, and years lived with disability for 328 diseases and injuries for 195 countries, 1990-2016: a systematic analysis for the Global Burden of Disease Study 2016 (2017). Lancet, 390 (10100), 1211-1259. doi: http://doi.org/10.1016/s0140-6736(17)32154-2

26. Roth, G. A., Johnson, C., Abajobir, A., Abd-Allah, F. et. al. (2017). Global, regional, and national burden of cardiovascular diseases for 10 causes, 1990 to 2015. Journal of the American College of Cardiology, 70 (1), 1-25.

27. Rothwell, J. A., Knaze, V., Zamora-Ros, R. (2017). Polyphenols: dietary assessment and role in the prevention of cancers, $20(6), 512-521$. 
28. Ford, E. S., Capewell, S. (2011). Proportion of the Decline in Cardiovascular Mortality Disease due to Prevention Versus Treatment: Public Health Versus Clinical Care. Annual Review of Public Health, 32 (1), 5-22. doi: http://doi.org/10.1146/annurevpublhealth-031210-101211

Received date 18.11.2019

Accepted date 16.12.2019

Published date 30.12.2019

Bobokalo Serhii, Senior Laboratory Assistant, Department of Cosmetology and Aromatology, National University of Pharmacy, Pushkinska str., 53, Kharkiv, Ukraine, 61002

E-mail: bobo7sv@gmail.com

Lyudmila Almakaieva, Doctor of Pharmaceutical Sciences, Professor, Department of Cosmetology and Aromatology, National University of Pharmacy, Pushkinska str., 53, Kharkiv, Ukraine, 61002

E-mail: almakaeva@ukr.net

Hanna Panfilova, Doctor of Pharmaceutical Sciences, Professor, Department of Organization and Economics of Pharmacy, National University of Pharmacy, Pushkinska str., 53, Kharkiv, Ukraine, 61002

E-mail: panf-al@ukr.net

Oksana Tsurikova, PhD, Assistant, Department Quality Management, National University of Pharmacy, Pushkinska str., 53, Kharkiv, Ukraine, 61002

E-mail: zurikova2008@gmail.com

UDC 547.655.6

DOI: 10.15587/2519-4852.2019.188127

\section{PRIMARY SCREENING OF THE BIOLOGICAL ACTIVITY OF HETEROCYCLIC AMI- NODERIVATIVES OF 2,3-DICHLORO-1,4-NAPHTOQUINONE}

\section{N. Polish, O. Voitsakhivska, N. Marintsova, L. Zhurakhivska, V. Novikov, S. Bohza}

Мета. Провести дослідження антимікробної та фунгіцидної активностей амінопіразольних похідних 2,3-дихлоро-1,4-нафтохінону та спрогнозувати їхню гостру токсичність.

Матеріали та методи дослідження. Протимікробну активність гетероциклічних амінопохідних нафтохінону 3a-d вивчали шляхом дифузї речовини в агар на твердому поживному середовищі та методом серійних розведень. Гостру токсичність для гризунів визначали методом моделювання QSAR, реалізованим в програмному забезпеченні GUSAR .

Результати. У роботі досліджено антимікробну та фунгіщидну активності нових гетерочиклічних амінопохідних нафтохінону, а також проведено визначення їх іп silico гострої токсичності для шурів за чотирма типами введення субстаниії.

Висновки. Дослідження амінопіразольних похідних нафтохінону дозволило виявити сполуки, які проявляють високу антимікробну активність по відношенню до тест-культури Candida tenuis, a caме: 2-хлоро-3-((1-метил-1Н-піразол-4-іл)аміно)нафтален-1,4-діон 3 а та 2-хлоро-3-((1-метил-1Н-піразол-3іл)аміно)нафтален-1,4-діон 3b. Встановлено, щзо усі синтезовані сполуки проявляють вибіркову бактеpio- $і$ фунгістатичну активності. Визначено методом QSAR нетоксичну сполуку 3 с при внутрішньочеревному шляху введення, а також нетоксичну сполуку $3 \boldsymbol{d}$ при підшкірному шляху введення

Ключові слова: амінопіразолопохідні 2,3-дихлоро-1,4-нафтохінону, первинний біологічний скринінг, програма GUSAR

Copyright (C) 2019, N. Polish, O. Voitsakhivska, N. Marintsova, L. Zhurakhivska, V. Novikov, S. Bohza This is an open access article under the CC BY license (http://creativecommons.org/licenses/by/4.0).

\section{Introduction}

Due to the increasing resistance of microorganisms to existing antimicrobial and fungicidal preparations, it is of great relevance to search for new biologically active compounds that could be used in the future for the production of low-toxic, microbial resistant drugs.
That is why heterocyclic amino derivatives of naphthoquinone, which have a wide range of pharmacological activity, in particular, antibacterial [1,2] antifungal [3], anticancer [4, 5], antiviral, anti-inflammatory and regenerating [6], occupy an important place among development of new drug substances. 